\title{
Coastal Zone Ecosystem Services: From science to values and decision making; a case study
}

\author{
T. Luisetti a , R.K. Turner ${ }^{\text {b }}$, T. Jickells ${ }^{c}$, J. Andrews $^{c}$, M. Elliott ${ }^{d}$, M. Schaafsma ${ }^{b}$, N. \\ Beaumont $^{e}$, S. Malcolm a, D. Burdon ${ }^{d}$, C. Adams ${ }^{c}$, W. Watts ${ }^{f}$ \\ a Centre for Environment, Fisheries \& Aquaculture Science (CEFAS), Pakefield Road, Lowestoft, Suffolk NR33 \\ $\mathrm{OHT}, \mathrm{UK}$ \\ ${ }^{b}$ Centre for Social and Economic Research on the Global Environment (CSERGE), School of Environmental \\ Sciences, University of East Anglia, Norwich, Norfolk NR4 7TJ, UK \\ c School of Environmental Sciences, University of East Anglia, Norwich, Norfolk NR4 7TJ, UK \\ d Institute of Estuarine \& Coastal Studies, University of Hull, Hull HU6 7RX, UK \\ e Plymouth Marine Laboratory, Prospect Place, Plymouth, Devon PL1 3DH, UK \\ f Environment Agency, 7 Canon Beck Road, London SE 16 7DJ, UK
}

\begin{abstract}
This research is concerned with the following environmental research questions: socio-ecological system complexity, especially when valuing ecosystem services; ecosystems stock and services flow sustainability and valuation; the incorporation of scale issues when valuing ecosystem services; and the integration of knowledge from diverse disciplines for governance and decision making. In this case study, we focused on ecosystem services that can be jointly supplied but independently valued in economic terms: healthy climate (via carbon sequestration and storage), food (via fisheries production in nursery grounds), and nature recreation (nature watching and enjoyment). We also explored the issue of ecosystem stock and services flow, and we provide recommendations on how to value stock and flows of ecosystem services via accounting and economic values respectively. We considered broadly comparable estuarine systems located on the English North Sea coast: the Blackwater estuary and the Humber estuary. In the past, these two estuaries have undergone major land-claim. Managed realignment is a policy through which previously claimed intertidal habitats are recreated allowing the enhancement of the ecosystem services provided by saltmarshes. In this context, we investigated ecosystem service values, through biophysical estimates and welfare value estimates. Using an optimistic (extended conservation of coastal ecosystems) and a pessimistic (loss of coastal ecosystems because of, for example, European policy reversal) scenario, we find that context dependency, and hence value transfer possibilities, vary among ecosystem services and benefits. As a result, careful consideration in the use and application of value transfer, both in biophysical estimates and welfare value estimates, is advocated to supply reliable information for policy making.
\end{abstract}

Keywords: System complexity, Ecosystem services, Stock, Flows, Context dependency, Value transfer

\section{Introduction}

Although our understanding of the functioning of coastal and marine ecosystems, their reactions to pressures, and their contribution to human well-being is still limited, it is clear that very valuable assets are at risk and require more sustainable and adaptive management. The flexibility focus of adaptive management allows us to adjust to the new knowledge and new drivers and pressures, including climate change. Adaptive management provides a practical framework for implementation of the Ecosystem Approach and ecosystem services concept. 
Ecosystem services valuation is currently faced with several challenges, including the need to better understand: socio-ecological system complexity, especially when valuing ecosystem services; ecosystems stock and services flow sustainability and valuation; the incorporation of the issues of scale and aggregation when valuing ecosystem services; and the integration of knowledge from diverse disciplines for governance and decision making (Valuing Nature Network, 2011).

Here we begin to look for insights into these issues by considering saltmarshes in two estuarine systems located on the English North Sea coast: the Blackwater and the Humber estuaries. We also acknowledge that evidence drawn from a small number of case study sites does not in itself provide robust evidence base. Although these estuaries are close geographically and geomorphically, and agricultural impacts from the catchments are probably broadly comparable (Shepherd et al., 2007), there are marked differences in other characteristics such as the legacy of varied industrial activities within the catchments (Neal and Robson, 2000; Neal and Davies, 2003).

The valuation of ecosystem services can become complex when, within a given ecosystem, interdependent ecosystem services are potentially available and fundamentally interlinked (Fisher et al., 2009). Our case study focuses on ecosystem services that can be jointly supplied by saltmarshes but can be independently valued in economic terms. The biophysical links between the configuration of ecosystem structure and processes that are present at a given time (stock) and the ecosystem services they provide over time (flows) are investigated through an examination of the carbon cycle. One possible way to tackle the problem of aggregation in valuation analysis is through value transfer, a method by which the value estimated for an ecosystem service or environmental benefit in a specific area (the study site) and time is applied to another area (the policy site) and time (Navrud and Ready, 2007). Valid and reliable benefit transfer requires a set of quite stringent conditions (Eftec, 2009); hence we highlight the need for the integration of knowledge about the value of ecosystem services from diverse disciplines from natural sciences (e.g. biogeochemistry, ecology, marine biology) to social sciences and environmental economics for improved decision making.

A set of global and regional socio-economic drivers such as land conversion and reclamation, agricultural runoff, pollution etc. leads to multiple environmental pressures on the coastal areas. Another key pressure on estuarine habitats, and their associated ecosystem services, is sea level rise. Because of sea level rise intertidal habitats are often 'squeezed' between the sea and sea defence or coastal protection structures (Doody, 2004).

The Fifth Assessment Report of the United Nations Intergovernmental Panel on Climate Change (IPCC 5) (Church et al., 2013) predicts between 19 and $83 \mathrm{~cm}$ of sea level rise by the end of the century, depending on greenhouse gas emission scenario, which concurs with an earlier estimate of $32 \mathrm{~cm}$ sea level rise by 2050 (Rignot et al., 2011). These are likely to be conservative estimates as the models are not yet able to accurately predict rapid dynamic changes in the Antarctic ice sheet (Church et al., 2013). If these more extreme predictions prove correct, such a rate of sea-level rise would be unprecedented on the timescale of human settlements. Response strategies and adaptation measures may well require a radical shift away from the 'hold the line' hard defences approach. A different flood defence and coastal protection strategy, able to selectively protect 'high value' coastal areas/assets while at the same time being able to maintain or expand intertidal habitats may need to be implemented. One option is coastal 
managed realignment (MR) (Elliott et al., 2014; Mazik et al., 2010), which has been implemented with different degrees of success in several estuaries in our study region (see the Online Managed Realignment Guide on-line map - http://www.abpmer.net/omreg/).

The case study includes a scenario analysis to investigate the future evolution of saltmarshes. Coastal and marine ecosystem services and related benefits may either be enhanced or put at risk depending on whether conservation policies such as the EU Directives on Habitats (92/43/EEC) and Birds (2009/147/EC) and the Marine Strategy Framework Directive (2008/56/EC) remain in place and/or are strengthened; or, on the other hand, a European policy dilution trend may become a reality. At the time of writing, extreme weather and flooding took place in Great Britain with devastating consequences (e.g. Somerset). We consider a baseline scenario in which some conservation policies such as managed realignment (MR) have already been put in place, securing a minimum of ecosystem services (business as usual scenario) and two extreme but still plausible future scenarios. These are a scenario in which implementation of conservation policies (e.g. an extended MR) is reinforced allowing maximisation of ecosystem services provision (optimistic scenario), and a scenario in which the implementation of conservation policies is weakened leading to continued degradation of saltmarshes at current estimated rates and to the loss of ecosystem services (pessimistic scenario). To test our ability to integrate biophysical sciences and economics, we explore the complexity of saltmarsh ecosystems through the stock and flows of carbon, and assess the economic value of the estuarine services through the goods/benefits they supply to society ('healthy' climate; food; and nature recreation) (Luisetti et al., 2011a). At the same time we clarify the meaning of 'marginality' (in economics terms) for the stock and the flow of ecosystem services when environmental changes such as those suggested by our optimistic and pessimistic scenarios are involved (Turner et al., 2003). We also explore the extent to which value transfer techniques could be applied.

\section{Methodological challenges}

In this paper we focus on some of the challenges faced when trying to construct a more robust evidence base for the incorporation of the ecosystem services concept into practical coastal management. We recognise that the provision of 'evidence', the process of policymaking and the delivery of policy are not separate activities. Coastal/marine management is part of a wider system that is composed of hierarchies and networks (including networked publics) and the interrelationships between them (Potts et al., 2014). Our focus is on the building and testing of the evidence base but with due regard for user needs.

\subsection{Challenge 1: socio-ecological system complexity when valuing ecosystem services}

Complexity in valuing ecosystem services can arise when within a given ecosystem interdependent ecosystem services are potentially available and fundamentally interlinked (Fisher et al., 2009). Coastal and marine system complexity (Fig. 1), following the framework set out by Fisher et al., can be conceptually separated into four components: basic pressures and structure, intermediate ecosystem services, final ecosystem services, and goods/benefits (Potts et al., 2014).

We investigate complexity in valuing ecosystem services by using a case study focusing on marine and coastal ecosystem services that can be jointly supplied but independently valued in economic terms. The economic efficiency of coastal MR as a policy response to the loss of 
intertidal ecosystem services has been analysed in previous studies on the Humber (Turner et al., 2007) and Blackwater (Luisetti et al., 2011a) estuaries. In our case study we first revisit the results of Luisetti et al. (2011a) for the Blackwater estuary study but re-analyse them under different future environmental scenarios. Based on these new biophysical and economic estimates, and using value transfer techniques (Navrud and Ready, 2007), we assess the ecosystem services and benefits provided by the MR sites in the Humber estuary.

The benefits identified and estimated in this study are: 'healthy climate' contributed to via carbon sequestration and storage, which is linked to climate regulation by removing $\mathrm{CO} 2$ from the atmosphere); food provision (fish, via fisheries production in nursery grounds), and nature recreation (nature watching and enjoyment via socially valued seascapes). We recognise that in some estuaries the supply of raw material and energy are also important but less so in our case study estuaries. Other benefits provided by the intertidal areas of these estuaries such as, for example, flood defence and erosion control and bioremediation of waste may also be important (see the Adaptation Sub-Committee Progress Report (2013) for a review of the services provided by coastal habitats specifically in the UK).

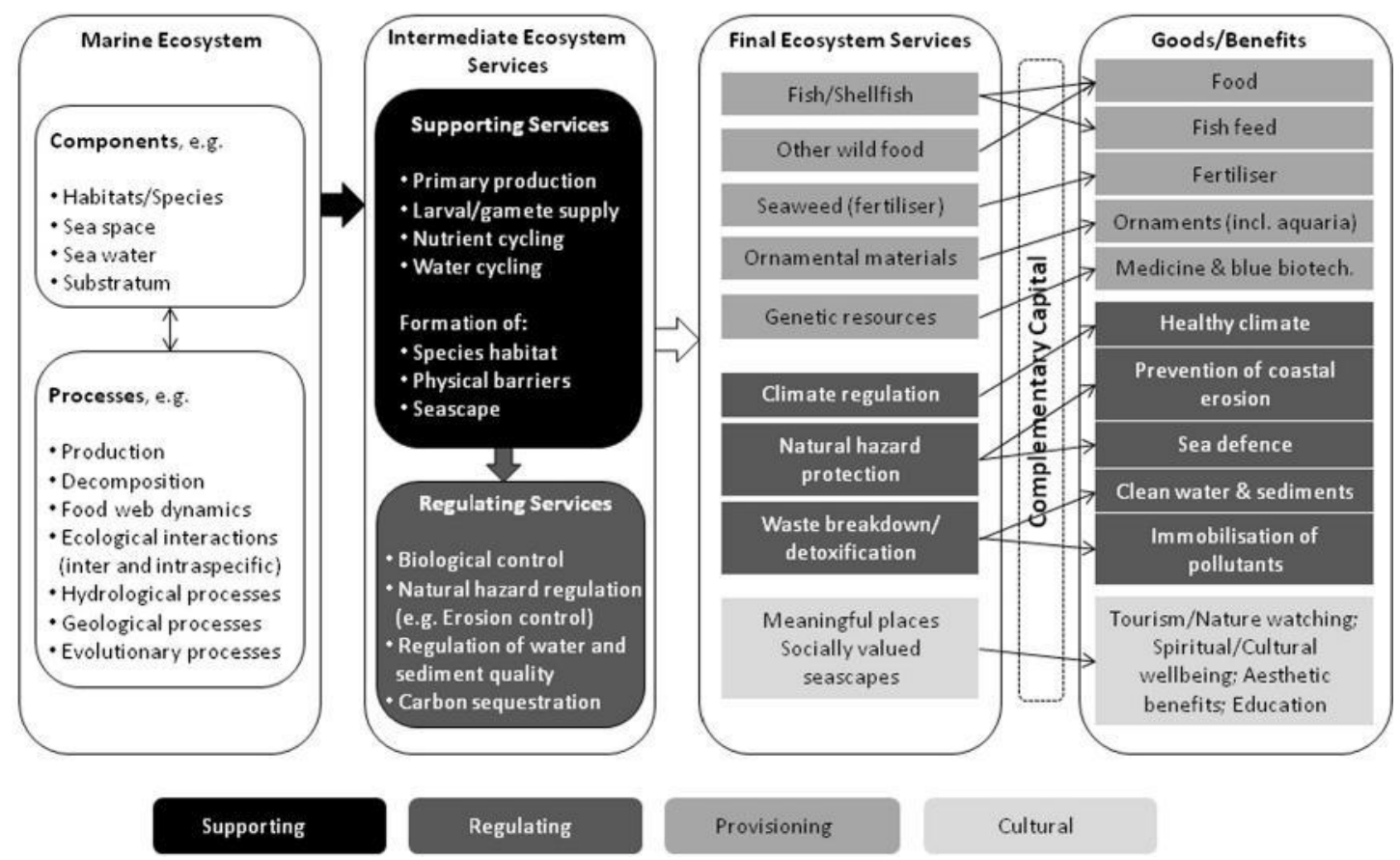

Figure 1: Classification of Coastal and Marine Ecosystem Services (Source: Potts et al., 2014).

\subsection{Challenge 2: ecosystem stock and services flow sustainability and valuation}

Coastal ecosystem stocks of natural capital (the ecosystem structure and processes and links to the abiotic environment) possess high biological productivity (McLusky and Elliott, 2004) and provide a diverse set of habitats and species, with a consequent flow of ecosystem services (such as carbon sequestration and storage) of significant benefit (value) to society (Fisher et al., 2009). We focus on the carbon sequestration and storage processes in order to help clarify the issues of stocks, flows and values through an interdisciplinary approach. We begin by examining organic carbon cycling, burial, and storage in the temperate estuarine mudflat-saltmarsh system (the 
stock). Coastal zone sedimentary carbon cycling has been reviewed by Andrews et al. (2011) and the role of sediments in sustaining ecosystem services has been reviewed by Apitz (2012) and the reader is referred to these papers for a fuller overview. Organic carbon input and cycling within the estuarine water column is itself complex (e.g. see Boyes and Elliott, 2006) and this complexity is maintained as organic carbon is deposited in estuarine sediments. Organic matter typically arrives in sediments either as coatings on minerogenic particles or as discrete particles (Andrews et al., 2011). The situation differs between mudflats, where organic carbon is almost wholly detrital or due to the microphytobenthos (e.g. diatoms), and saltmarshes, where much organic carbon is directly coupled to plant growth and particularly manifests as root material in sediments. Once deposited in sediment, organic matter is typically subject to a series of aerobic and anaerobic microbial decay mechanisms (e.g. Bianchi, 2007). The most labile organic compounds (e.g. phytoplankton cells) decay at a faster rate than the more refractory ones such as higher plant roots. This early stage of 'burial' in sediments is not simple and is particularly complicated by bioturbation (Gray and Elliott, 2009). However, overall these decay mechanisms can serve as an intermediate ecosystem service; for example the microbiallydriven denitrification reaction uses the dissolved nutrient compound nitrate in seawater to help oxidise organic matter (e.g. see Bianchi, 2007), a reaction that consumes the nitrate, acting as a natural 'waste treatment' process, that helps improve water quality (Seitzinger et al., 2006; Andrews et al., 2006; Turner et al., 2008). However, this reaction also produces a small but significant quantity of the potent greenhouse gas nitrous oxide (Andrews et al., 2006; Middelburg and Levin, 2009; Jickells and Weston, 2011; Adams et al., 2012), which through its role in global warming is a dis-benefit rather than 'a service'.

Even at the level of a single example reaction there are clear environmental positives and negatives that need balancing. Most of the above processes, which we can broadly class as 'cycling', operate on timescales of hours to decades, but at some point, on timescales of decades, the rate of cycling becomes sufficiently slow that we can consider it negligible. Then the residual (or net) organic carbon burial becomes semipermanent and classed as storage (Andrews et al., 2011). This net organic carbon storage (final ecosystem service) can be directly measured (e.g. Andrews et al., 2008; Sousa et al., 2010). Moreover it can be viewed as an ecosystem service benefit in terms of an atmospheric $\mathrm{CO} 2$ equivalent that has been removed from the atmosphere, thus reducing greenhouse gas impacts. Storage (a service flow over time) in estuarine mudflatsaltmarsh systems (the stock) operates on timescales of decades (Andrews et al., 2008) and centuries (Allen and Rae, 1987) to millennia (Rees et al., 2000; Andrews et al., 2000).

Clearly the net storage term increases as long as there is sediment available for deposition and the carbon supply to that sediment is maintained; it then follows that the final ecosystem service becomes more valuable, which implies we should protect, and even enable deposition of muddy estuarine accumulation (Turner et al., 2007; Luisetti et al., 2011a). In the UK east coast setting appropriate for this case study, coastal erosion and reworking of offshore sediments provide adequate sediment to allow sediment accretion at managed realignment sites (Shepherd et al., 2007); clearly this may not be the case in other geographic settings. Such deposition cannot occur when man-made defences interfere with sedimentation processes, but MR schemes can augment this mechanism. This is important given that there is potential for a significant decline in the $\mathrm{C}$ sequestration service and accompanying benefits due, for example, to sea level change, climatic change and change in sediment supply. Carbon storage and the related climate change mitigation effect can be difficult to assess because the (positive) capture of greenhouse gases 
has to be balanced against the (negative) release of greenhouse gases into the atmosphere during carbon storage.

However, the release of greenhouse gases, particularly methane is lower in saltmarsh areas than in fresh water marsh areas (Andrews et al., 2006). Net $C$ sequestration has an economic value based on the environmental damage avoided by storing rather than emitting each ton of CO2, which may help to meet reduction targets set by the UK Climate Change Act 2008, as detailed in the Low Carbon Transition Plan (DECC, 2009). From an evaluation point of view, we consider the economic value of the flow of benefits provided by intertidal ecosystems and also the current ecosystem stock and its potential supply of benefits. The ecosystem stock accounting price value is estimated, in accounting terms, at a precise point in time (Banzhaf and Boyd, 2012); we review the debate following Costanza et al. (1997) over the valuation of such entities. The paper in the journal Nature by Costanza et al. (1997) estimated the value of global ecosystem services at $\$ 33$ trillion and led to a protracted debate and controversy over the 'true' value of the natural environment. The value of nature is a multidimensional concept, which includes monetary value but also more qualitative measures. The complete 'commodification' of nature is an ever-present danger to be avoided according to critics of monetary valuation. The position adopted here is that many (but not all) ecosystem services can be meaningfully expressed in monetary terms and that this type of calculus has 'political' purchase that can be used to further conservation efforts in the real world. We do not agree with the argument put forward by some that the ecosystem services approach results in 'cherry picking' and therefore is an unsound basis for biodiversity conservation (Seppelt et al., 2011; Apitz, 2013). Conservation and management at the landscape scale can encompass one or more habitats or ecosystems and therefore a range of ecosystem services. The framework set out by Fisher et al. (2009) and adopted by the UK National Ecosystem Assessment (UKNEA, 2011) distinguishes between final services and the supporting ecological processes and structure. In any given policy trade off context involving development pressures and ecosystem conservation it is often the case that valuing a restricted bundle of final ecosystem services is sufficient to demonstrate an economic case in favour of conservation (Balmford et al., 2002). If this is not the case, it is necessary to bear in mind that the total economic value of an ecosystem is always less than the total system value (Turner et al., 2003) and therefore the economic data presented to policymakers is only one component of the evidence base which can be supplemented by other scientific or ethical/moral evidence.

The Costanza et al. (1997) global ecosystem services estimation has been attacked on a number of grounds including that the aggregate value was not necessarily the sum of the parts, and that US $\$ 33$ trillion was more than global income and therefore peoples' ability to pay (Heal, 2000). Further work (Howarth and Farber, 2002) sought to defend the Costanza et al., 1997 approach by arguing that the estimates of ecosystem services value were analogous to National Income Accounting entities such as GDP with a constant set of value weights. The underlying rationale here is that the aggregate measure is a quantity parameter (the stock concept), and, while it is related to value, it does not directly value the planet's ecosystem services in total. In this sense it is an accounting price measure of the quantity of ecosystem services holding prices constant, where the measures are not based on economic theory but on accounting rules. In this stock accounting context the criticism related to peoples' budget constraint and ability to pay is not relevant, because the measure is based on virtual (not real) 
prices and virtual incomes (i.e. incomes adjusted to enable individuals to hypothetically pay for the services).

For the income and expenditure accounts to balance, the total expenditure must be less than actual and virtual income. The current extent of European coastal blue carbon (the carbon storage service provided by salt marshes and sea grasses) has, for example, an accounting stock price (value) of about US $\$ 180$ million, valued against a Social Cost of Carbon estimate (Luisetti et al., 2013). Such total (stock) values can be estimated and compared for two different points in time as a heuristic to help to appreciate the change in natural capital. This viewpoint is, however, controversial and is not supported by many mainstream economists. For them the only relevant measure is the marginal economic value. However, we argue that estimates of aggregate stock accounting price value can play a valuable role in the 'politics' of the environment and can heighten awareness of the overall importance of ecosystem services relative to and in combination with other contributors to human well-being.

For economic valuation it is important to be able to quantify and evaluate gains or losses in stock assets and consequent service flows (analogous to net GDP) ${ }^{1}$. Now instead of holding prices constant, we seek to determine marginal economic value as it relates to an incremental increase in a set of ecosystem services over time and space. When the final ecosystem services value relates only to non-market services, it can be combined with GDP (in the same way as relevant pollution and other externalities are internalised) to yield a more green GDP measure. The present value of a discounted flow of ecosystem services values can contribute to stock of wealth accounts such as the Inclusive Wealth account (UNU-IHDP and UNEP, 2012). An important consideration is that the flow economic values and the stock accounting price values cannot be aggregated. They are complementary in the sense that they provide different dimensions of the magnitude and significance of ecosystem services.

\subsection{Challenge 3: the incorporation of the issue of scale when valuing ecosystem services}

The issue of scale is investigated because of ecosystem services context dependency, both in terms of biophysical estimates and welfare value estimates. We examine the extent to which context dependency is a binding constraint limiting aggregation. As fieldwork can be very expensive, we investigate the possibility of transferring biophysical estimates and welfare value estimates for the ecosystem services provided by the Blackwater estuary to the Humber estuary. As both estuaries are on the same coastline we assume that they are both geomorphologically and socio-economically similar even if not identical. Here we assume similarity and explore the validity of this assumption.

Transferability of biophysical estimates appears to be broadly valid for regional carbon storage, as Chmura et al. (2003) suggests that saltmarshes in a similar climate will have similar sequestration rates. Moreover, for the case study described here there is empirical evidence that the carbon storage terms for the Southern North Sea tidal fringe are remarkably similar (see Andrews et al., 2011). We are less certain about the variability of greenhouse gas emissions although Sousa et al. $(2010,2012)$ suggest that while carbon, nitrogen and methane cycling in

\footnotetext{
${ }^{1}$ GDP reflects the financial (market) value of all final goods and services produced within a country within a certain period. Net Domestic Product (net GDP) is GDP net of the depreciation on capital goods, and thereby reflects how much capital has been consumed over the year.
} 
intertidal areas are variable in space and time, they do not vary systematically between plant species or even between saltmarshes or mudflats. On this basis we make the reasonable assumption that Adams (2012) net $\mathrm{C}$ sequestration estimate in mature managed realignment marsh for the Blackwater is a suitable estimate for the other estuaries located on this same coastline. Clearly there will be some variability in the carbon storage terms, but when the much bigger uncertainty around greenhouse gas emissions is factored in, these become trivial. The transferability of this function on a global scale is much more challenging. As the issue of the sustainability, the store is also complex: at the century scale natural saltmarsh systems are transitory and should migrate geomorphically as climate and sea level change (Chmura, 2011); although in many situations such natural migration is no longer possible due to coastal development.

On the other hand, context dependency was considered to be a major issue for fisheries productivity in saltmarshes because ecological conditions and functions may differ between estuaries. Hence we concluded that while transfer may be possible, in this study the existing biophysical estimates could not be reliably transferred without a more in depth analysis and possibly a targeted data collection (e.g. fish community analysis, age of population, survival rate, etc.) (Burdon et al., 2011).

Value transfer of willingness to pay (WTP) values is accepted practice in environmental economics studies, for example, studies of value function transfer of wetlands are reported (Brander et al., 2011). In our case study we transfer the WTP estimates for the value of the Blackwater re-created saltmarshes (the amenity and recreational value) into an optimistic scenario of re-created saltmarsh in the Humber. We also consider a pessimistic scenario of lost saltmarshes because of European policy reversal for both the Blackwater and the Humber. However it is necessary to consider various constraints on value transfer such as, for example, the fact that gains and losses are not valued equivalently by people in some contexts and marginal value functions can be nonlinear. Hence we make a number of assumptions in order to adjust the estimates of Luisetti et al. (2011a). We consider three main issues:

a) The primary valuation study in the Blackwater addressed saltmarsh creation, so the WTP values refer to gains in saltmarsh area. Gains are valued by assessing WTP, but environmental losses are typically valued by assessing public Willingness-to-Accept (WTA) compensation for a loss. The difference between WTP and WTA estimates is a technical and empirical issue and is the subject of continued debate in the valuation literature. In empirical studies, WTA for losses has been found to be larger than WTP for gains, which can be attributed primarily to substitution effects and loss aversion (Pearce, 2002). Loss aversion indicates that people weigh losses more heavily than gains (Kahneman and Tversky, 1984). Theoretically, the divergence between WTP and WTA is minor when there are sufficient substitution options for the good lost (Hanemann, 1999). Economic values for losses (WTA) can therefore be approximated with WTP estimates for gains when substitutes are plentiful, where a WTP value will give a conservative estimate. This is therefore the assumption made in our analysis.

b) The original Blackwater study (Luisetti et al., 2011a) estimated a value function for gains between 10 and 70 hectares. Therefore, the preferences of people for habitat changes beyond this range are less certain. Application of this WTP function to larger 
changes in habitat may be problematic and the area changes in our VNN scenarios are greater than 70 hectares. $^{2}$

c) The original WTP function is additive, i.e. total WTP is a summation of the monetary values of area, distance, access and species recovered. This means that WTP values for distance, access and species are not scaled to the extent of the saltmarsh area. So even for very small increases in saltmarsh area this function will produce relatively high WTP estimates, whilst the added hectares may not actually be able to support species or be of recreational interest. In addition, the effect of area changes is included in the WTP function after applying a log transformation. This generally implies that the additional WTP for an additional hectare decreases as the total area increases, reflecting theoretically expected satiation effects. However, it also suggests that for very small changes (e.g., $<5$ ha) the WTP per ha for the attribute AREA is unrealistically high, whilst for additional saltmarshes of much more than 70 ha (the upper boundary of the variable), the WTP value is not much higher than for marshes of 70 ha. For example, the WTP of a typical household living 11 miles from a 70 ha new saltmarsh is $£ 12 / y r$, while for an area of 1084 ha (>15 times larger) the WTP is $£ 15 / y r$ (only 1.25 times larger).

The gain/loss issue is easily addressed because a test showing the respondents two maps with different scales, which included multiple substitutes in the area, was conducted in the Luisetti et al. (2011a) valuation study. This revealed that respondents were aware of the many substitutes close to the Blackwater. Therefore, we used WTA for losses as a proxy for WTP estimates for gains. To address the second and third issues described above, we assume that the function is applicable to areas $<10$ hectares. This relates to the first 4 years of the pessimistic scenario when the new saltmarsh loss will be $<10$ ha. For the large gains in area, as well as for losses of $>70$ ha, we provide two estimates. The first estimate (option A) is based on the assumption that the WTP functions can be used beyond the range of the AREA variable without adjustments. This option provides a lower bound estimate of the saltmarsh values in the optimistic scenario. The second option (B) uses the additional value per household for an increase from 69 to 70 ha new saltmarsh (e.g. £0.0156/yr/ha). This value is then applied to any additional ha of saltmarsh beyond $>70$ ha, assuming a linear function from that point onwards. Under this assumption, the WTP of a typical household living at 11 miles from a 1084 ha new saltmarsh is now $£ 28 / \mathrm{yr}^{3}$

\footnotetext{
${ }^{2}$ Note that in the aggregation procedure we also have an issue with the range of the at-tribute distance used in the original study. Therefore, the aggregated WTP values do not ac $\neg$ count for potential positive WTP/WTA of people beyond $32 \mathrm{~km}$ from the newly created saltmarshes.

${ }^{3}$ Option C would be to split the new/lost areas into sections of $70 \mathrm{ha}$, apply the equartions to each section, and aggregate those values. This would lead to much higher esti-mates than option B and is therefore not included in this paper
} 


\section{Case study analysis}

\subsection{Case study areas: the Humber and the Blackwater estuaries (English North Sea coast)}

The Humber estuary is a relatively large and complex estuary with two major river systems (the Rivers Trent and Ouse) meeting within the estuary and draining more than $20 \%$ of England. The catchment includes areas of intensive agriculture and upland areas used for low intensity sheep grazing. This region has a history of mining and industrial activity dating back to Roman times (Neal and Robson, 2000; Neal and Davies, 2003). Although most of the estuarine industrial activities are now closed or operating on a reduced scale with less environmental impact, a significant estuarine contamination legacy remains (GarcíaAlonso et al., 2011). The Humber continues to be an important commercial and population centre (Cave et al., 2003). In the past, the estuary has been subject to major land claim of intertidal areas with a loss of $>90 \%$ of its intertidal area, which has greatly reduced the capacity for the storage and processing of carbon, nutrients and contaminants (Jickells et al., 2000; Andrews et al., 2006; McLusky and Elliott, 2004). According to the Humber Estuary Shoreline Management Plan, given the estimated loss of saltmarshes and mudflats due to future sea level rise, the recreation of intertidal areas is highlighted as a priority (Edwards and Winn, 2006). MR schemes are currently in progress in the estuary and an extension of these is planned at a number of sites (Mazik et al., 2010).

The Blackwater has also been subject to land claim of intertidal areas, the re-creation of which is also considered a priority because of the risks related to sea level rise. The Blackwater is located in the Essex coastal region, which has relatively small lowland rivers with small catchments and low flows. The region is largely semi-rural with a catchment dominated by intensive agriculture with small amounts of industrial legacy contaminants. Nitrate concentrations from agriculture are however high (Shepherd et al., 2007).

It is possible to argue that in the context of the next 50-100 years deleterious system change is likely to result in both the Humber and the Blackwater estuary. This will be driven by a combination of rapid sea-level rise, coupled with climatic change resulting in increased winter rainfall, increased incidence of extreme events and increased storminess of the North Sea. Rapid sealevel rise is expected to cause erosion of mudflats and sediments due to substantial changes in the symmetry of the tidal prism compounded by a lack of sediment supply. Under natural conditions the estuary would widen with sea level rise (Allen and Rae, 1987), but the presence of sea walls in most of the modern estuary will result, under a 'business as usual' scenario, in rapidly deepening water with no intertidal space for sedimentation (Andrews et al., 2000). Under these conditions, even without erosion, the present intertidal area will be drowned and its ecosystem service provision potentially reduced. If, however, the present rate of global sealevel change $\left(3.1 \pm 0.4 \mathrm{~mm} \mathrm{yr}^{-1}\right.$ ) (Nerem et al., 2010) increases, it is arguable that coastal protection will not be able to operate under 'business as usual' conditions and estuaries will need to 'make space for water' (Defra, 2004, 2005), but also for sediment to help rebuild mudflat and saltmarsh and to restart ecosystem service provision. It is also of note that isostatic adjustment of the English east coast will increase the relative sea level rise (Ducrotoy and Elliott, 2008). The case study area is presented in Fig. 2. 


\subsection{Scenario analysis}

Two scenarios and a baseline are considered, over the period 2010-2110, and are related to previous scenario studies (Langmead et al., 2007; Turner et al., 2007; Luisetti et al., 2011a). These are:

- Baseline/minimum ecosystem services (MinES): economic growth is combined with environmental protection, with realignment undertaken to reduce flood defence expenditure and compensate for past and future intertidal habitat loss in compliance with the Habitats Directive.

- Optimistic/maximum ecosystem services (MaxES): primary objective is habitat creation.

- Pessimistic/loss of ecosystem services (LESS): the existing defences are maintained to a satisfactory standard, wherever possible, but intertidal habitat will be lost due to continued development and coastal squeeze.

Calculations for the stock and the flow estimates of ecosystem services provided by the estuaries are based on the extent of saltmarshes estimated for each scenario. As reported in Table 1, the extent of the areas of saltmarsh for both estuaries in the baseline and optimistic scenario comes from previous studies (Luisetti et al., 2011a; Turner et al., 2007; Andrews et al., 2000). Evidence from the literature suggests that the colonization of managed realignment sites may take place relatively quickly with large numbers of plants establishing, especially in areas with rapid accretion such as the Humber estuary (Boyes \& Allen, 2007), however with respect to community development this may take decades to develop (Mazik et al., 2007; Mossman et al., 2012). Dagley (1995) observed that on the Blackwater the colonization rate and order of establishment at the Brancaster and Northey Island MR sites was similar, the second with 23 plant species established in 3 years. Mossman et al. (2012) found evidence of convergence between the vegetation communities in the MR site and those of reference marshes after 5 years. This was also shown by Wolters et al. (2008) whose state that it took approximately 5 years for species diversity in the Tollesbury restoration site to become similar to a local reference marsh. In the United states, Morgan and Short (2002) for marshes in the Great Bay Estuary suggested that species richness could be within $95 \%$ confidence limits of reference marshes within 7 years, reaching their mean value after 12 years. Based on the evidence provided by the literature, especially for the Blackwater and Humber estuary we assume that full provision of ecosystem services will be effective after 5 year from realignment in the Blackwater and 15 years in the Humber estuary and that this will be maintained until 2110. 


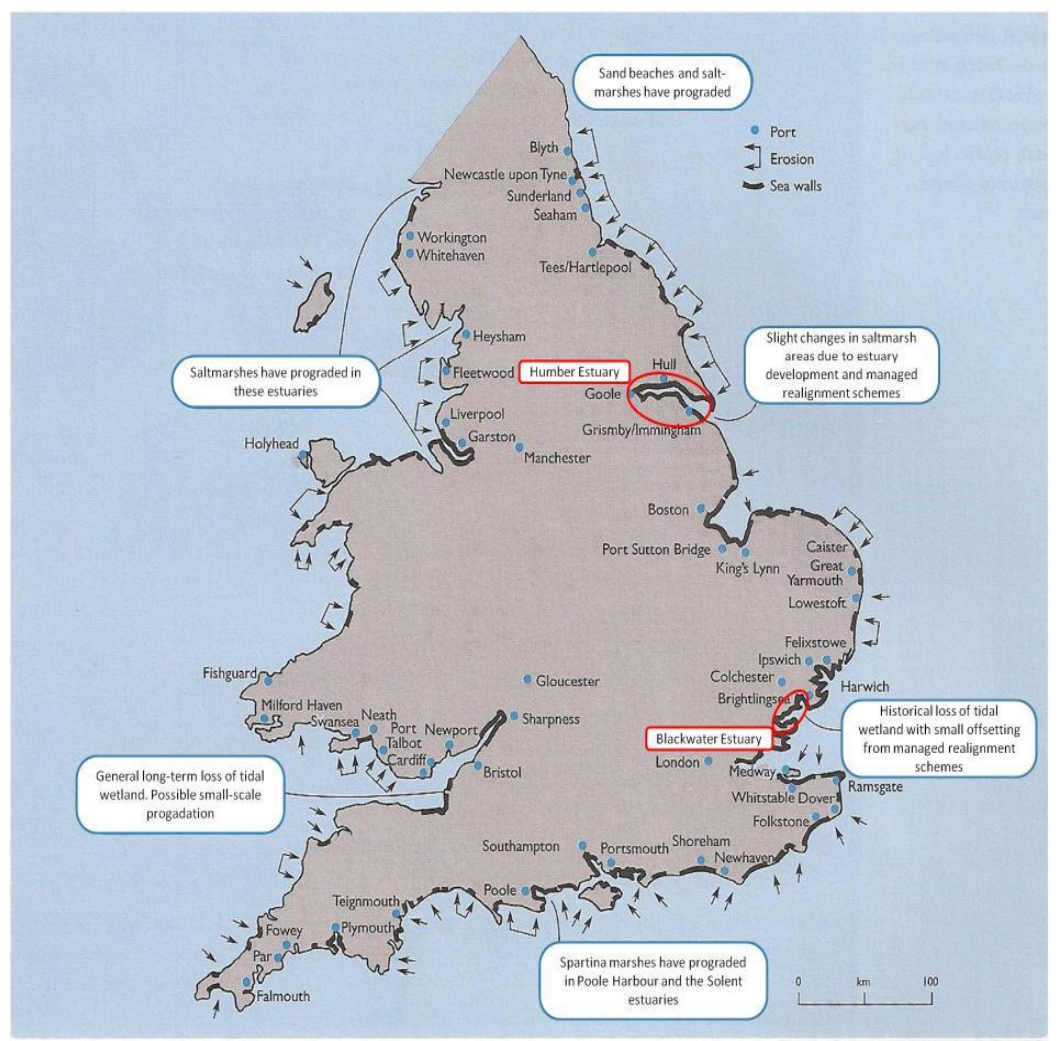

Figure 2: Coastline changes in England and Wales where arrows show zones of erosion and the heavy lines show areas of accretion. The study sites discussed in this paper are highlighted in red. Modified from Figure 9.2 in O'Riordan et al. (2000).

Table 1: Area extent (ha) per scenario in the Blackwater and the Humber estuaries.

\begin{tabular}{lll}
\hline Scenario/Estuaries & Blackwater $^{1}$ & Humber $^{2}$ \\
\hline Baseline/MinES & 1,084 & 11,100 \\
Optimistic/MaxES & $+2,404$ & +176 \\
Pessimistic/LESS & -244 & $-2,500$ \\
\hline
\end{tabular}

Notes: 1. Luisetti et al. (2011a); 2. Turner et al. (2007) and Andrews et al. (2000). The figures for the pessimistic scenarios have been calculated in this study.

Table 1 also shows the potential future loss of saltmarsh under the pessimistic scenario. In this scenario, implementation of the EU Habitats (92/43/EEC) and Birds (2009/147/EC) Directives allowing for re-creating of saltmarshes will become limited, and intertidal habitats are squeezed between the defences and the rising sea level. This scenario follows the predictions for saltmarsh loss because of sea level rise reported in Jones (2011): 4.5\% of saltmarshes lost over the last twenty years (i.e. 1990-2010), although losses are projected to reach $8 \%$ by 2060 . A decrease of $4.5 \%$ for 20 years is equal to a saltmarsh loss of $0.225 \%$ per annum. The uncertainty around future climate change is high. The future may present us with smooth as well as abrupt changes in the loss of our coastlines. Although we acknowledge that other evidence may suggest a different percentage loss of saltmarshes for the UK coastline, for the illustrative 
purposes of this study we assume that the loss of saltmarshes will continue at the fixed pace of $0.225 \%$ per annum calculated on the baseline in 2010 till 2110 (i.e. 2.44 ha/year loss in the Blackwater, and 25 ha/year loss in the Humber estuaries). For the Blackwater this is equal to a loss of 244 ha after 100 years and for the Humber to 2,500 ha after 100 years.

A more likely scenario would be a mix of realignment and continued loss of saltmarshes. What we show here is an example of what we could gain or lose in plausible but extreme circumstances.

It is assumed that, subject to appropriate sustainable management, the flow of many ecosystem service benefits provided by saltmarshes (e.g. 'healthy' climate (carbon sequestration and storage); food (fish), and nature recreation) can be enjoyed over time into the future. As a consequence, future flows of services value have to be discounted to give their present value. The concept of sustainability aims to guarantee to future generations at least the same level of environmental resources enjoyed by the present generation. However, the future is by definition uncertain. Whether and how future technology will be able to help future generation is uncertain. For this reason it has been observed (Frederick et al., 2002) that individuals prefer rather to have something today than in the future. This is known as individual time preference. If the belief of the policy maker is that future generations will be better-off, then a relatively high discount rate will be applied to estimate the efficiency of a project/policy. On the contrary if the belief is that future generations will be worse-off, then a relatively low discount rate will be applied. Some authors even advocate a zero discount rate (Broome, 1995). Current British policy appraisal (Treasury Green Book) suggests the use of a declining discount rate - the further away in the future the benefits manifest themselves, the lower the discount rate. For this reason, in this application, we use the Green Book suggested declining discount rates schedule. In our case study, the present value of the services flow for a time horizon of 100 years in each scenario is calculated applying the declining discount rate scheme as recommended by the UK Government (HMT, 2011).

\section{3. 'Healthy' climate valuation}

The latest estimates of net carbon storage per year (Adams et al., 2012) for the Blackwater estuary, amended to take account of greenhouse gases production and global warming potential of $\mathrm{CH} 4$ and $\mathrm{N} 2 \mathrm{O}$, have been used in this study (Table 2). Following atmospheric science convention, emissions are reported as positive and sequestration as negative values. Table 2 illustrates that while the $\mathrm{N} 2 \mathrm{O}$ issue is important, the overall saltmarsh development represents a net sink for greenhouse gases, i.e. there is a net climate change mitigation benefit. A first estimate of net carbon burial $(-1.15)$ is based on mature MR marsh sampling in the Blackwater. The other estimate $(-0.94)$ shows the $C$ sequestration potential in natural saltmarshes (e.g. Atriplex portuacoides, Limonium vulgare, Armeria maritima, Triglochin maritimum). We use the first estimate for the MR scenario analysis (MaxES), and the second for the calculation of the current stock of the $\mathrm{C}$ sequestration service and for the pessimistic scenario (LESS). Table 2 is based on the estimate of a $5.4 \mathrm{~mm}$ sedimentation rate, which is an acceptable estimate for long term surface elevation change, given a regional sea-level rise of $\sim 6 \mathrm{~mm}$ per year in the Blackwater estuary (NRA, 1994) and assuming that the sampling area is currently in equilibrium with sea-level rise and remains so. 
Table 2: Estimated net carbon burial per year in the Blackwater estuary.

\begin{tabular}{lllll}
\hline & $\begin{array}{l}\text { Gross C burial } \\
\mathrm{tC} / \mathrm{ha} / \mathrm{yr}\end{array}$ & $\begin{array}{l}\mathrm{CH}_{4} \\
\mathrm{tC} / \mathrm{ha} / \mathrm{yr}\end{array}$ & $\begin{array}{l}\mathrm{N}_{2} \mathrm{O} \\
\mathrm{tC} / \mathrm{ha} / \mathrm{yr}\end{array}$ & $\begin{array}{l}\text { Net C burial } \\
\text { (C sequestration }) \\
\mathrm{tC} / \mathrm{ha} / \mathrm{yr}\end{array}$ \\
\hline $\begin{array}{c}\text { Mature managed } \\
\text { realignment marsh }\end{array}$ & -1.19 & 0.012 & 0.028 & -1.15 \\
Natural Saltmarsh & -1.27 & 0.008 & 0.315 & -0.94 \\
\hline
\end{tabular}

Note: 1. Figures are amended to take account of greenhouse gases production (i.e. net figures). 5.4 $\mathrm{mm}$ assumed sedimentation rate.

Table 3 summarises the estimated flow changes per year in carbon storage capacity (based on the estimates in Table 2) for the Blackwater and Humber estuaries under two different scenarios: optimistic/MaxES (increase) and pessimistic/LESS (decrease). In the pessimistic scenario, it is assumed that losses of intertidal habitat occur. In this scenario, we assume that intertidal mud and sand with saltmarsh is lost and replaced by subtidal sediment. We assume this subtidal sediment produces GHGs, although the flux is not yet constrained. To try and account for this, as shown in Table 3 , we assume that the actual $\mathrm{C}$ storage capacity lost will be equal to $90 \%$ of the net annual C storage capacity shown in Table 2 .

It was assumed that carbon sequestration is linearly related to saltmarsh area since, as discussed above, we assume that the carbon storage rate per gram of sediment is rather uniform in these habitats. Table 4 shows the value of the $C$ sequestration potential for the intertidal habitats that could be gained with the optimistic scenario or lost with the pessimistic one in the Blackwater and Humber estuary. For the purpose of sensitivity analysis, the changes of carbon storage service flows in the two scenarios are valued by two different methods: the social cost of carbon (SCC), which measures the monetary value of the avoided carbon releases to the atmosphere because of storage (damage cost avoided method), and the Department of Energy and Climate Change (DECC) prices for non-traded carbon (DECC, 2011), for which figures are calculated using the marginal abatement cost (clean-up cost) method. As in Luisetti et al. (2011a) three different SCC prices were considered: a lower value of $£ 7 / \mathrm{tC}$ (Arrow et al., 1996; Pearce et al., 1996; Li et al., 2004); a middle value of $£ 30 / t C$ (Pearce et al., 1996; Tol, 2005); and an upper value of £230/tC (Stern, 2007; Nordhaus, 2007). DECC (2011) provides non-traded C prices till 2100. For the illustrative purposes of this study, we assume that the trend showed in the relevant year values between 2096 and 2100 will continue till 2110. Also, since DECC prices are defined for units of tCO2, the net carbon (C) sequestration values of Table 2 were converted ${ }^{44}$ to net carbon dioxide (CO2) values in Table 3 and used for the calculation of the present value results presented in Table 4.

\footnotetext{
${ }^{4}$ The mass of $\mathrm{C}$ is first divided by 12.01 to bring everything to a base value, and the re $\neg$ sult is then multiplied by the mass of CO2 (44.01).
} 
Table 3: Estimated change over the time period 2010-2110 in C sequestration potential for the Blackwater and Humber estuaries under two different scenarios: optimistic/MaxES and pessimistic/ LESS.

\begin{tabular}{|c|c|c|c|c|}
\hline & Intertidal Area (ha) & Net $\mathrm{C}$ sequestration ( $\mathrm{tC} / \mathrm{ha} /$ year) & Total C storage in tC/yr & Total C storage in $\mathrm{tCO}_{2} / \mathrm{yr}$ \\
\hline \multicolumn{5}{|l|}{ Blackwater } \\
\hline Optimistic/MaxES Scenario & $+2,404$ & -1.15 & $+2,765$ & $+10,132$ \\
\hline $\begin{array}{l}\text { Pessimistic/LESS Scenario } \\
\text { (loss of } 90 \% \text { of C storage capacity) }\end{array}$ & $-2.44 / \mathrm{yr}$ & $\begin{array}{l}-0.846 \\
(90 \% \text { of }-0.94)\end{array}$ & -2.06 & -7.55 \\
\hline \multicolumn{5}{|l|}{ Humber } \\
\hline Optimistic/MaxES Scenario & +176 & -1.15 & +202 & +743 \\
\hline $\begin{array}{l}\text { Pessimistic/LESS Scenario } \\
\text { (loss of } 90 \% \text { of C storage capacity) }\end{array}$ & $-25 / \mathrm{yr}$ & $\begin{array}{l}-0.846 \\
(90 \% \text { of }-0.94)\end{array}$ & -21.15 & -77.5 \\
\hline
\end{tabular}

Following Howarth and Farber (2002), we use the 'market' price to calculate the value of the stock of saltmarshes in terms of $\mathrm{C}$ sequestration and storage in the Blackwater and Humber estuaries, measuring the aggregate service provision at a specific point in time: i.e. 2010. To calculate the stock of carbon storage service we have used the mean price of traded carbon (a proxy for the current market price of CO2). The average EU Allowance spot (i.e. market) price in 2010 was $€ 15 / \mathrm{tCO} 2$ (Rickels et al., 2010; Chevallier, 2010). At those prices, the accounting value of the saltmarsh stock in terms of $C$ sequestration (natural saltmarshes) in the Blackwater and Humber estuaries in 2010 is reported in Table 5.

\subsection{Amenity and recreation}

In the original Blackwater estuary case study (Luisetti et al., 2011a), a specific stated preferences (survey based) technique to estimate the amenity and recreation benefit potential of re-created intertidal habitats after MR in the estuary was undertaken. Based on the ecosystem services framework, the benefits of expected water quality improvements and the non-use value of biodiversity maintenance (including fisheries output not sold in the market) were assumed to be captured by the value estimated for the amenity and recreational value of the newly created intertidal habitats. The valuation procedure is service and location specific. In another context water quality may be a final service and should be independently valued. The survey asked the respondents to answer a choice experiment (CE) exercise. In a CE, respondents are asked to choose between alternative goods or policies that are described according to several characteristics (attributes) with varying levels. In Luisetti et al. (2011a), the attributes considered were: the extent of the salt marsh area re-created (AREA), the number of protected bird species observable (BIRD), the distance from respondent's home to the new recreational site (DIST), whether there is public access to the new area (ACCESS), and the hypothetical annual cost expressed by an increment of the local council tax paid by each respondent to implement MR schemes and re-create saltmarshes (TAX). The attribute ACCESS reveals how much people value the possibility of 'using' the newly created intertidal habitat. Use values are related to the actual or possible use of the good in question. Non-use values are the values that individuals assign to some good because its existence is thought to be important even though there is no actual or possible use (Turner et al., 2003). Here, we use the variable BIRD as a proxy for non-use (e.g. biodiversity) value.

From the stated choices between alternative policy-scenarios, the WTP of respondents for the attributes can be estimated. The resulting WTP/household/year from the study by Luisetti et al. (2011a) is presented in Eq. (1): 


$$
\begin{aligned}
\text { WTP } & =1.087^{*} \operatorname{Ln}(\triangle \mathrm{AREA})+3.522 * 1(\mathrm{BIRD} 5)-0.052 * \text { DIST } \\
& \left.+4.217^{*} 1 \text { (ACCESS }\right)
\end{aligned}
$$

The variable AREA is logtransformed (reflecting diminishing values per additional ha) and BIRD5 is a dummy variable representing the highest level of interest by respondents in non-use values.

We use this WTP function to consider two different policy scenarios: optimistic/MaxES and pessimistic/LESS for saltmarshes in the Blackwater estuary. We present two WTP estimates for these scenarios: one based on use and non-use values of the saltmarshes, and a conservative estimate based predominantly on use values and in which the WTP related to the variable BIRD is excluded.

The variable DIST provides a key determinant of the aggregated WTP. So called 'distancedecay effects' reflect that the respondent WTP diminishes with increasing distance between the good (related to the final ecosystem service) of the investigation and the respondent residence. Significant distance decay values were revealed in the econometric analysis of the CE in Luisetti et al. (2011a). We account for this distance-decay effect in the aggregation of WTP estimates per households over the relevant population.

We based the aggregation on the number of households in urban centres in a range of 32 miles from the MR site Abbott's Hall, an internationally recognised and locally well-known successful MR example in the Blackwater estuary ${ }^{5}$. The number of households per urban centre was based on the 2001 Census Statistics (Office for National Statistics, 2004) ${ }^{6}$. This provides a representative, yet lower-bound estimated of aggregate WTP for the area, since not all households within 32 miles are included. Distance from each urban centre to the MR site was calculated using Google Maps. We assume that people can only reach the new saltmarshes by car.

Aggregate WTP is calculated by multiplying the number of households in a centre by the mean household WTP of that centre for the policy under consideration, taking the travel distance between the centre and the MR site into account, and summed over all relevant centres. The estimated present values (PV) of the recreation benefit flows over a time horizon of 100 years are reported in Table 6. For the positive scenario, the PV are estimated based on the assumption that benefits only start to accrue after 5 years in the Blackwater estuary MR site. Values of this scenario range from GBP 78 million (use values only, option A) to GBP 328 million (use and non-use values, option B). The (negative) benefit flows of the pessimistic/LESS scenario increase each year as more saltmarsh is lost and vary between GBP 43 million (option B, use values) to GBP 86 million (option $B$, use and non-use values).

\footnotetext{
${ }^{5}$ Luisetti et al. (2011b) show that the distance-decay effect depends on the range of DIST attribute show to respondents in the CE survey. Respondents of a subsample for which the option included a MR site nearby (2-32) showed significantly different distance-decay values than respondents in a 'distant' subsample.

${ }^{6}$ Adapted from data from the Office for National Statistics licensed under the Open Government Licence v.1.0 (Table KS20 Household composition).
} 
Table 4: Present value of carbon sequestration flows for the Blackwater and Humber estuaries over 100 years (2010-2110) discounted following the declining discount rate scheme of the UK Green Book (HMT, 2011) under two different scenarios: optimistic/MaxES; pessimistic/LESS $\left(£^{\star} 1000\right)$. ${ }^{*}$ DECC (2013) provides non-traded C prices till 2100. Here, we assume that the trend showed in the relevant year values between 2096-2100 will continue till 2110.

\begin{tabular}{|c|c|c|c|c|}
\hline & \multicolumn{3}{|c|}{$\mathrm{SCC} / \mathrm{tC}$} & \multirow{2}{*}{$\frac{\mathrm{DECC}{ }^{*} \text { Price } / \mathrm{tCO}_{2}}{\text { All relevant year values }(\mathrm{f})}$} \\
\hline & £ 7 & £ 30 & £ 230 & \\
\hline \multicolumn{5}{|l|}{ Blackwater } \\
\hline MaxES Scenario & 527 & 2,257 & 36,670 & 45,500 \\
\hline LESS Scenario & 0.5 & 2 & 15 & 36 \\
\hline \multicolumn{5}{|l|}{ Humber } \\
\hline MaxES Scenario & 28 & 123 & 941 & 3,000 \\
\hline LESS Scenario & 3 & 15 & 117 & 325 \\
\hline
\end{tabular}

In option A, the WTP function is used beyond the range of the AREA variable without adjustments, which provides a lower bound estimate of the WTP per area increase. In Option B, we apply the additional value per household for an increase from 69 to 70 ha new saltmarsh (e.g. $£ 0.0156 / \mathrm{yr} / \mathrm{ha}$ for any additional ha of saltmarsh beyond $>70 \mathrm{ha}$ ). Option B results in considerably higher benefit flows than option A for the optimistic/MaxES scenario, whilst for the pessimistic/LESS scenario the differences are fairly small, partly because the total saltmarsh loss in 2110 is 244 ha.

Here the economic value of the amenity and recreation service estimated for the Blackwater estuary is transferred to the Humber estuary making use of a benefit transfer value technique. In previous studies of the Humber estuary (Turner et al., 2007), the value of recreation and amenity was based on a meta-analysis of wetlands areas around the world. We argue that using a UK based study is likely to provide more accurate estimates because the socio-economic conditions and ecosystem services are likely to be more similar. For this benefit transfer exercise, we use the coefficients in Eq. (1), and for each variable the data of the Humber estuary. Although the area around the Humber is more populated than the area surrounding the Blackwater estuary (i.e. Essex county), socio-economic characteristics appear to be similar (Office for National Statistics, 2011). Again, we choose some urban centres in the Humber estuary surrounding the MR site of interest, assume that people can only reach the new saltmarshes by car, and calculate distances between the centre and the MR site.

Table 7 presents the estimated present values for the optimistic/ MaxES and pessimistic/LESS scenarios for the MR site in the Humber estuary. For the Humber study, the recreation and amenity benefits in the optimistic scenario are assumed to start after 15 years after the establishment of the MR site (176 ha). In the pessimistic/LESS scenario, the total area lost in 2110 is 2,500 ha, immediately leading to losses in recreation and amenity values.

The estimated benefits of the optimistic/MaxES scenario range from GBP 33 million (option A, use values) to GBP 48 million (option $B$, use and non-use values). The difference between the estimated benefits of the optimistic/MaxES scenario and the losses under the pessimistic/ LESS 
scenario are larger using the calculation method of option $B$ than under option $A$. This is because the diminishing marginal value assumed for any additional ha under option $A$, which implies that the much larger area lost in the pessimistic/LESS scenario (compared with the optimistic scenario), does not result in a proportional decrease in monetary value.

Table 5: Accounting C stock value in the Blackwater and Humber estuaries in 2010.

\begin{tabular}{llllll}
\hline Estuaries & $\begin{array}{l}\text { Area extent in the } \\
\text { baseline (ha) }\end{array}$ & $\begin{array}{l}\text { Net } \mathrm{C} \mathrm{tCO}_{2} / \text { year in } \\
\text { natural saltmarshes }\end{array}$ & $\begin{array}{l}\text { Total stock net C sequestration } \\
\text { potential/year }\end{array}$ & $\begin{array}{l}\text { Accounting value of the stock } \\
\text { in 2010 }\left(€^{*} 1,000\right) \text { at } € 15 / \mathrm{tCO}_{2}\end{array}$ & $\begin{array}{l}\text { Accounting value of the stock in } \\
2010\left(€^{*} 1,000\right) \\
\text { Conversion rate: } 1 €=€ \text { 0.858347 }\end{array}$ \\
\hline $\begin{array}{l}\text { Blackwater } \\
\text { Humber }\end{array}$ & 1,084 & -0.94 & 3,740 & 56 & 48 \\
\hline
\end{tabular}

Table 6: Present value of the aggregated willingness to pay (WTP) flows for recreation in the Blackwater saltmarshes and over a time horizon of 100 years (2010-2110) discounted following the declining discount rate scheme of the UK Green Book (HMT, 2011) under the two different scenarios $(£ * 1000)$.

\begin{tabular}{llcc}
\hline Blackwater & & Option A & Option B \\
\hline \multirow{2}{*}{ MaxES Scenario } & WTP use and non-use values & $+102,972$ & $+327,780$ \\
& WTP mainly use values & $+78,728$ & $+303,556$ \\
\multirow{2}{*}{ LESS Scenario } & WTP use and non-use values & $-84,395$ & $-85,682$ \\
& WTP mainly use values & $-56,594$ & $-42,501$ \\
\hline
\end{tabular}

Note: In option A, the WTP function is used beyond the range of the AREA variable without adjustments. Option (B) applies the additional value per household for an increase from 69 to 70 ha new saltmarsh (e.g. £0.0156/yr/ha for any additional ha of saltmarsh beyond $>70$ ha.

Table 7: Present value of the aggregated willingness to pay (WTP) flows for recreation in the Humber saltmarshes under the different scenarios and over a time horizon of 100 years (20102110) discounted following the declining discount rate scheme of the UK Green Book (HMT, 2011) $(£ * 1000)$.

\begin{tabular}{llrr}
\hline Humber & & Option A & \multicolumn{1}{c}{ Option B } \\
\hline MaxES Scenario & WTP use and non-use values & 45,901 & 48,268 \\
& WTP mainly use values & 33,187 & 35,554 \\
\multirow{2}{*}{ LESS Scenario } & WTP use and non-use values & $-76,874$ & $-126,611$ \\
& WTP mainly use values & $-57,281$ & $-106,281$ \\
\hline
\end{tabular}

Note: In option A, the WTP function is used beyond the range of the AREA variable without adjustments. Option (B) applies the additional value per household for an increase from 69 to 70 ha new saltmarsh (e.g. £0.0156/yr/ha for any additional ha of saltmarsh beyond $>70$ ha.

\section{Conclusions}

One aim of this study was to test the possibility of providing ecosystem services benefit estimates within the same country, or at least the same region, for subsequent use in cost-benefit analysis (CBA). For this purpose, the study builds on the previous CBA results of Turner et al. (2007) and 
Luisetti et al. (2011a) that evaluated managed realignment (MR) schemes for the estuaries located on the East coast of England (the Humber estuary and the Blackwater estuary respectively). The schemes were appraised over short (25 years) and mid/long (50/100 years) time horizons and against three scenarios of future sea level rise and more or less extensive MR. The advantages of a "low regret" policy such as MR were apparent under any of the three scenarios for the Blackwater estuary when a time horizon of 50/100 years was considered. Tradeoffs such as lost agricultural land because of realignment were incorporated in the analysis. In Luisetti et al. (2011a) an anomaly was found when the most ecological scenario and a short time period such as 25 years were taken into account - the short term realignment costs (breaching existing walls and building secondary lines of defense) where much higher than the short run benefits. However, it is also the case that benefits (co-benefits) other than flood defense may be delivered if MR schemes are implemented. Other findings of this study relate to the spatial scale of biophysical and welfare value estimates and their transferability across areas and different policy contexts. Among the ecosystem services and benefits considered in this analysis (see Table 8 ), the $\mathrm{C}$ sequestration and storage service, underpinning the 'healthy' climate societal benefit, was found to be particularly suited to cross-disciplinary analysis.

Table 8: Case study expert judgment on reliability of function transfer results.

\begin{tabular}{|c|c|c|c|c|}
\hline Ecosystem goods/benefits & $\begin{array}{l}\text { BIOPHISICAL ESTIMATE OF } \\
\text { FINAL ECOSYSTEM SERVICE }\end{array}$ & $\begin{array}{l}\text { ECONOMIC } \\
\text { VALUE }\end{array}$ & TRANSFERABILITY & METHODS \\
\hline 'Healthy' climate & +++ & ++ & ++ & $\begin{array}{l}\text { - Assumptions about biophysical data transferability supported by real data findings; } \\
\text { - Use of SCC and DECC prices. }\end{array}$ \\
\hline Food & --- & +++ & $+1-$ & $\begin{array}{l}\text { Further investigation needed as currently biophysical data are lacking and different } \\
\text { methodologies may be applied. }\end{array}$ \\
\hline Recreation & NA & ++ & $+1-$ & $\begin{array}{l}\text { - Assumptions to overcome methodological limitations encountered in the original } \\
\text { case study source of the main data (WTP); } \\
\text { - Assumptions about socio-economic characteristic similarities for transferability of } \\
\text { WTP values supported by real data. }\end{array}$ \\
\hline
\end{tabular}

Within the case study, for this ecosystem service, biophysical estimates are transferable without any adjustment and the accounting and economic value for carbon sequestration can be estimated using carbon prices and global social cost of carbon estimates respectively. The same argument may not be applicable at a bigger scale (e.g. European level) where the differences in the climate zones may result in more significant differences between biophysical estimates as well as socio-economic characteristics. The transferability of the amenity and recreational benefit in both scenarios was possible but subject to several assumptions. On a more extensive scale, those assumptions may increase in number and complexity mitigating against an extensive use of the value transfer practice. Food (fish, via fisheries production in nursery grounds) transferability may also be possible. However transferability of fisheries production function is not straightforward. Fish production estimates within managed realignment sites in the Humber estuary at the time of the analysis were less-advanced than for the Blackwater estuary (Fonseca, 2009; Luisetti et al., 2011a), therefore it was not possible to carry out a similar valuation for food as in Luisetti et al. (2011a), nor to investigate transferability options for the Humber due to lack of data (Burdon et al., 2011). Future research should test the appropriateness of using the same production function estimated for the Blackwater and applying the data collected for the Humber to this production function. It would also be valuable to estimate a new specific production function for the Humber using Humber data; and transfer the estimates of the Blackwater estuary to the Humber. Therefore, we can conclude that, although subject to the well-known methodological limitations affecting the benefit transfer technique, depending on the similarity between the biophysical conditions of an ecosystem service in the case study and the policy site 
and the data availability of that service, transferability of ecosystem benefits may be possible at the same country level. However, careful examination of the similarities of biophysical conditions and socio-economic characteristics between sites, as well as the technical transferability possibilities of production and socioeconomic functions, are essential before undertaking any benefit transfer. Outside the boundaries of the same country, biophysical conditions and socioeconomic characteristics may differ significantly from the case study site limiting the meaningful application of value transfer in the policy site when ecosystem services, which are context dependent by definition, are concerned.

There are many more ecosystem services and benefits which arise from estuarine habitats in addition to the three detailed here. Two significant ecosystem services are flood defence and erosion control and contaminant and nutrient cycling, future research should seek to include these and other services as sustainable management will require a holistic inclusive approach to ecosystem services. The recently completed TIDE project has taken further the estimation of these ecosystem services (see http://www.tide-toolbox.eu/reports/). It can be argued that informed decision making requires integration between disciplines helping to tackle societal and environmental change issues from a pluralistic perspective and leading to policy relevant tools and means to adapt the governance structure for better future coastal management. To achieve this aim a holistic and inclusive approach to ecosystem management is necessary and the ecosystem approach can play a key role in this. Issues key to the successful valuation of ecosystem services and benefits, and addressed in this study, are:

- A recognition of socio-ecological system complexity when valuing ecosystem services, dealt with in this study in biophysical and economic terms through the application of an ecosystem approach and a related ecosystem services valuation framework for the assessment and valuation of the goods/benefits provided by the marine ecosystem and ecosystem services;

- $\quad$ The need to distinguish between ecosystem stock and service flow sustainability and valuation, investigated in this study through the carbon cycle in saltmarshes, with recommendations on how to value stocks and flows of ecosystem services via accounting and economic values respectively; and

- $\quad$ An acknowledgement of the difficulties posed by the issues of scale and transferability when valuing ecosystem services, and their incorporation in policy appraisal methods such as CBA, investigated using a case study highlighting ecosystem services context dependency and potential transfer of ecosystem services values, both in terms of biophysical estimates and welfare value estimates. Another sister VNN project "Uncertainty and Scale" reviewed a selection of ecosystem services in order to identify common themes related to scale and uncertainty.

Results from this study suggest that because of socio-ecological system complexity, careful consideration is required in the use and application of benefit transfer to ecosystem service values, both in terms of biophysical data and welfare value estimates to supply reliable information for policy making. 


\section{Conflict of interest}

The authors of this manuscript do not have any actual or potential conflict of interest to disclose to Science of the Total Environment.

\section{Acknowledgements}

This work was a Valuing Nature Network project, funded by the UK Natural Environment Research Council, with additional funding from Department for Environment, Food and Rural Affairs.

\section{References}

Adams CA, Andrews JE, Jickells TD. Nitrous oxide and methane fluxes vs. carbon and nutrient burial in new intertidal and salt marsh sediments. Sci Total Environ 2012. http://dx.doi.org/10.1016/..scitotenv.2011.11.058.

Adaptation Sub-Committee progress report. Managing the land in a changing climate; 2013.

Allen JRL, Rae JE. Late Flandrian shoreline oscillations in the Severn estuary: A geomorphological and stratigraphical reconnaissance. Philos Trans R Soc Lond B 1987; 315: 185-230. [and Application. Policy Brief No. 3].

Andrews JE, Samways G, Dennis PF, Maher BA. Origin, abundance and storage of organic carbon and sulphur in the Holocene Humber Estuary - emphasising human impact on storage changes. In: Shennan I, Andrews JE, editors. Holocene Land-Ocean Interaction and Environmental Change around the North Sea, 166. Geological Society Special Publication; 2000. p. 145-70.

Andrews JE, Burgess D, Cave RR, Coomes EG, Jickells TD, Parkes DJ, et al. Biogeochemical value of managed realignment, Humber estuary UK. Sci Total Environ 2006; 371: 19-30. http://dx.doi.org/10.1016/j.scitotenv.2006.08.021.

Andrews JE, Samways G, Shimmield GB. Historical storage budgets of organic carbon, nutrient and contaminant elements in saltmarsh sediments: Biogeochemical context for managed realignment, Humber Estuary, UK. Sci Total Environ 2008; 405:1-13. http:// dx.doi.org/10.1016/i.scitotenv.2008.07.044.

Andrews JE, Jickells TD, Adams CA, Parkes DJ, Kelly SD. Sediment record and storage of organic carbon and the nutrient elements $(\mathrm{N}, \mathrm{P}$, and $\mathrm{Si})$ in estuaries and near-coastal seas. In: Wolanski E, McLusky DS, editors. Treatise on estuarine and coastal science, vol. 4. Waltham: Academic Press; 2011. p. 9-38.

Apitz SE. Conceptualizing the role of sediment in sustaining ecosystem services:Sedimentecosystem regional assessment (SEcoRA). Sci Total Environ 2012; 415:9-30.

Apitz SE. Ecosystem services and environmental decision making: Seeking order in complexity. Integr Environ Assess Manag 2013;9: 214-30.

Arrow K, Cline WR, Maeler KG, Munasinghe M, Squitieri R, Stiglitz JE. Intertemporal equity, discounting, and economic efficiency. Climate change 1995: Economic and social dimensions - Contribution of Working Group III to the second assessment report of the intergovernamental panel on climate change. Cambridge: Cambridge University Press; 1996. p. 125-44. 
Balmford A, Bruner A, Cooper P, Costanza R, Farber S, Green RE, et al. Economic reasons for conserving wild nature. Science 2002; 297:950-3.

Banzhaf HS, Boyd J. The architecture and measurement of an ecosystem services index. Sustainability $2012 ; 4: 430-61$.

Bianchi TS. Biogeochemistry of Estuaries. Oxford: Oxford University Press; 2007 [706 pp.]. Boyes SJ, Allen JH. Topographic Monitoring of a Middle Estuary Mudflat, Humber Estuary. UK - Anthropogenic Impacts and Natural Variation. Mar Pollut Bull 2007;55: 543-54.

Boyes SJ, Elliott M. Organic matter and nutrient inputs to the Humber Estuary, England. Mar Pollut Bull 2006; 53(1-4):136-43.

Brander LM, Brauer I, Gerdes H, Ghermandi A, Kuik O, Markandya A, Navrud S, Nunes PALD, Schaafsma M, Vos H, Wagtendonk A. Using meta-analysis and GIS for value transfer and scaling up: Valuing climate change induced losses of European wetlands. Environ Res Econ 2011. DOI: 10.1007/s10640-011-9535-1.

Broome J. Discounting the future. Philos Public Affairs 1995; 20:128-56.

Burdon D, Atkins JP, Bhatia N. Ecosystem services and societal benefits provided by estuarine saltmarsh. Report to Associated British Ports \& Environment Agency, December 2011; 2011. [Report No. SBB338-F1-2011].

Cave RR, et al. The Humber catchment and its coastal area: From UK to European perspectives. Sci Total Environ 2003; 314:31-52.

Chevallier J. Carbon prices during the EU ETS phase II: Dynamics and volume analysis. http://econpapers.repec.org/paper/halwpaper/halshs-00459140.htm, 2010.

Chmura GL. What Do We need to Assess the Sustainability of the Tidal Salt Marsh Carbon Sink? Ocean Coast Manag 2011. http://dx.doi.org/10.1016/j.ocecoaman.2011.09.006.

Chmura GL, Anisfeld SC, Cahoon DR, Lynch JC. Global carbon sequestration in tidal, saline wetland soils. Global Biogeochem Cycles 2003; 17:1111.

Church JA, Clark PU, Cazenave A, Gregory JM, Jevrejeva S, Levermann A, et al. Sea level change. In: Stocker TF, Qin D, Plattner G-K, Tignor M, Allen SK, Boschung J, Nauels A, Xia Y, Bex V, Midgley PM, editors. Climate change 2013: The physical science basis. Contribution of Working Group Ito the fifth assessment report of the intergovernmental panel on climate change. Cambridge, United Kingdom and New York, NY, USA: Cambridge University Press; 2013.

Costanza R, d'Arge R, de Groot RS, Farber S, Grasso M, Hannon B, et al. The value of the world's ecosystem services and natural capital. Nature 1997; 387:253-60.

Dagley JR. Northey Island managed retreat scheme. English Nature Research Reports, 128. Peterborough: English Nature; 1995.

Department of Energy and Climate Change. Carbon Valuation in UK Policy Appraisal: A Revised Approach; 2009. p. 128.

Department for Environment, Food, and Rural Affairs (DEFRA). Making space for water. Taking forward a new Government strategy for flood and coastal erosion risk management in 
England. First Government response to the autumn 2004 Making space for water consultation exercise; 2005. p. PB10516 [Available at http://archive.defra.gov. uk/environment/flooding/documents/policy/strategy/strategy-response1.pdf].

Department for Environment, Food, Rural Affairs (DEFRA). Making space for water: Developing a new government strategy for flood and coastal erosion risk management in England: A consultation exercise; 2004. p. PB 9792 [Available at www.defra.gov. $\mathrm{uk} /$ corporate/consult/waterspace/consultation.pdf].

Department of Energy and Climate Change (DECC). A brief guide to the carbon valuation methodology for UK policy appraisal; 2011.

Doody JP. 'Coastal squeeze' - an historical perspective. J Coast Conserv 2004; 10(1-2): 12938.

Ducrotoy J-P, Elliott M. The science and management of the North Sea and the Baltic Sea: Natural history, present threats and future challenges. Mar Pollut Bull 2008; 57:8-21.

Edwards AMC, Winn PSJ. The Humber Estuary, Eastern England: Strategic planning of flood defences and habitats. Mar Pollut Bull 2006; 53:165-74.

Eftec. Valuing environmental impacts: Practical guidelines for the use of value transfer in policy and project appraisal - Value transfer guidelines submitted to Department for Environment, Food and Rural Affairs (Defra); 2009.

Elliott M, Cutts ND, Trono A. A typology of marine and estuarine hazards and risks as vectors of change: A review for vulnerable coasts and their management. Ocean Coast Manag 2014; 93:88-99.

Fisher B, Turner RK, Morling P. Defining and Classifying Ecosystem Services for Decision Making. Ecol Econ 2009; 68(3):643-53.

Fonseca L. Fish utilisation of managed realignment areas and saltmarshes in the Blackwater Estuary, Essex, S. E [England PhD thesis] Queen Mary University of London; 2009.

Frederick S, Loewenstein G, O'Donoghue T. Time discounting and time preference: A critical review. J Econ Lit 2002; 40(2):351-401.

García-Alonso J, Greenway GM, Munshi A, Gómez JC, Mazik K, Knight AW, et al. Biological responses to contaminants in the Humber Estuary: Disentangling complex relationships. Mar Environ Res 2011; 71(4):295-303.

Gray JS, Elliott M. Ecology of marine sediments: Science to management. Oxford: OUP; 2009 [260 pp.].

Hanemann M. The economic theory of WTP and WTA. In: Bateman I, Willis K, editors. Valuing environmental preferences: Theory and practice of the contingent valuation method in the US, EU and developing countries. Oxford: Oxford University Press; 1999. p. 42-96.

Heal Geoffrey. Nature and the Marketplace. Washington, D.C.: Island Press; 2000

HMT. Green book: Appraisal and evaluation in central government HMSO, London; 2011. Howarth RB, Farber S. Accounting for the value of ecosystem services. Ecol Econ 2002; 41(2002):421-9. 
Jickells TD, Weston K. Nitrogen cycle - External cycling: Losses and gains. In: Wolanski E, McLusky DS, editors. Treatise on Estuarine and Coastal Science, vol. 5. Waltham: Academic Press; 2011. p. 261-78.

Jickells T, Andrews J, Samways G, Sanders R, Malcolm S, Sivyer D, et al. Nutrient fluxes through the Humber estuary - Past, present and future. Ambio 2000; 29:130-5.

Jones L. Coastal Margins. The UK National Ecosystem Assessment Technical Report. UK National Ecosystem Assessment Cambridge: UNEP-WCMC; 2011.

Kahneman D, Tversky A. Choices, Values, and Frames. Am Psychol 1984;39(4):341-50. Langmead O, McQuatters-Gollop A, Mee LDEuropean lifestyles and marine ecosystems: Exploring challenges for managing Europe's seas, vol. 43. Plymouth, UK: University of Plymouth Marine Institute; 2007.

Li H, Berrens RP, Bohara AK, Jenkins-Smith HC, Silva CL, Weimer DL. Would developing country commitments affect US households support for a modified Kyoto protocol? Ecol Econ 2004; 48:329-43.

Luisetti T, Turner RK, Bateman IJ, Morse-Jones S, Adams C, Fonseca L. Coastal and marine ecosystem services valuation for policy and management: Managed realignment case studies in England. Ocean Coast Manag 2011a; 54(3):212-24. http://dx.doi.org/10. 1016/i.ocecoaman.2010.11.003.

Luisetti T, Bateman I, Turner RK. Testing the fundamental assumption of choice experiments: Are values absolute or relative? Land Econ 2011b; 87:284-96.

Luisetti T, Jackson EL, Turner RK. Valuing the European "coastal blue carbon" storage benefit. Mar Pollut Bull 2013; 71:101-6.

Mazik K, Smith JE, Leighton A, Elliott M. Physical and biological development of a newly breached managed realignment site, Humber estuary, UK. Mar Pollut Bull 2007; 55: 564-78.

Mazik K, Musk W, Dawes O, Solyanko K, Brown S, Mander L, et al. Managed realignment as compensation for the loss of intertidal mudflat: A short term solution to a long term problem? Estuar Coast Shelf Sci 2010; 90:11-20.

McLusky DS, Elliott M. The estuarine ecosystem: Ecology, threats and management. 3rd ed. Oxford: Oxford University Press; 2004.

Middelburg JJ, Levin LA. Coastal hypoxia and sediment biogeochemistry. Biogeosciences 2009; 6:1273-93.

Morgan PA, Short FT. Using functional trajectories to track constructed salt marsh development in the Great Bay estuary, Maine, New Hampshire, U.S.A. Restor Ecol 2002;10:461-73.

Mossman HL, Brown MJH, Davy AJ, Grant A. Constraints on salt marsh development following managed coastal realignment: Dispersal limitation or environmental tolerance? Restor Ecol 2012; 20:65-75.

Navrud S, Ready R, editors. Environmental value transfer: Issues and methods. Dordrect, The Netherlands: Springer; 2007. [290 pp.]. 
Neal C, Davies H. Water quality fluxes for eastern UK rivers entering the North Sea: A summary of information from the Land Ocean Interaction Study (LOIS). Sci Total Environ 2003; 314-316:821-82.

Neal C, Robson AJ. A summary of river water quality data collected within the Land-Ocean Interaction Study: Core data for eastern UK rivers draining to the North Sea. Sci Total Environ 2000; 251-252:585-665.

Nerem RS, Chambers D, Choe C, Mitchum GT. Estimating Mean Sea Level Change from the TOPEX and Jason Altimeter Missions. Mar Geodesy 2010;33(1 suppl. 1):435. [http:// sealevel.colorado.edu/l.

Nordhaus W. A Review of the Stern Review on the Economics of Climate Change. J Econ Lit 2007;XLV: 686-702.

NRA. Blackwater catchment management plan: Consultation report. Anglian Region: National Rivers Authority; 1994.

Office for National Statistics. Census 2001, Key Statistics - Urban areas in England and Wales KS20 Household composition; 2004 [(Excel sheet 1823Kb) release date: June 2004]. Office for National Statistics. Census 2011; 2011.

O'Riordan T, Andrews JE, Samways G, Clayton K. Coastal processes and management. Chapter 9. Environmental Science for Environmental Management. 2nd Edition. (Ed. by T. O'Riordan). Harlow, U.K.: Prentice Hall; 2000. p. 243-66.

Pearce D. The role of 'property rights' in determining economic values for environmental costs and benefits. Bristol: Report to the Environment Agency; 2002 [December 2002].

Pearce D, Cline WR, Achanta AN, Fankhauser S, Pachauri RK, Tol RSJ, et al. The social cost of climate change: Greenhouse damage and the benefits of control. In: Bruce JP, Lee H, Haites EF, editors. Climate change 1995: Economic and social dimensions Contribution of Working Group III to the second assessment report of the intergovernmental panel on climate change. Cambridge: Cambridge University Press; 1996. p. 179-224.

Potts T, Burdon D, Jackson E, Atkins JP, Saunders J, Hastings E, et al. Do Marine Protected Areas deliver flows of ecosystem services to support human welfare? Mar Policy 2014;44: 139-48.

Rees JG, Ridgway J, Ellis S, Knox, RWO'B, Newsham R, Parkes A. Holocene sediment storage in the Humber Estuary. In: Shennan I, Andrews JE, editors. Holocene LandOcean Interaction and Environmental Change around the North Sea, 166. Geological Society Special Publication; 2000. p. 119-43.

Rickels W, Görlich D, Oberst G. Explaining European emission allowance price dynamics: Evidence from Phase II. Kiel working papers n. 1650. Kiel institute for world economy; 2010.

Seitzinger S, Harrison JA, Bohlke JK, Bouwman AF, Lowrance R, Peterson B, et al. Denitrification across landscapes and waterscapes: A synthesis. Ecol Appl 2006; 16:2064-90. 
Seppelt R, Dormann CF, Eppink FV, Lautenbach S, Schmidt S. A quantitative review of ecosystem service studies: Approaches, shortcomings and the road ahead. J Appl Ecol 2011; 48:630-6.

Shepherd D, Burgess D, Jickells T, Andrews J, Cave R, Turner RK, et al. Modelling the effects and economics of managed realignment on the cycling and storage of nutrients, carbon and sediments in the Blackwater estuary UK. Estuar Coast Shelf Sci 2007; 73: 355-67.

Sousa Al, Lillebø Al, Pardal MA, Caçador I. Productivity and nutrient cycling in salt marshes: Contribution to ecosystem health. Estuar Coast Shelf Sci 2010; 87(4): 640-6.

Sousa Al, Lillebø Al, Risgaard-Petersen N, Pardal MA, Caçador I. Denitrification: An ecosystem service provided by salt marshes. Mar Ecol Prog Ser 2012; 448:79-92.

Stern N. The economics of climate change: The Stern review. Cambridge, UK: Cambridge University Press; 2007.

Tol RSJ. The marginal damage costs of carbon dioxide emissions: An assessment of the uncertainties. Energy Policy 2005; 33:2064-74.

Turner RK, Paavola J, Cooper P, Farber S, Jessamy V, Georgiu S. Valuing nature: Lessons learned and future research directions. Ecol Econ 2003; 46:493-510.

Turner RK, Burgess D, Hadley D, Coombes EG, Jackson N. A cost-benefit appraisal of coastal managed realignment policy. Glob Environ Chang 2007; 17:397-407.

Turner RK, Georgiou S, Fisher B. Valuing ecosystem services: The case of multifunctional wetlands. London and Washington DC: Earthscan; 2008.

UK National Ecosystem Assessment. The UK National Ecosystem Assessment Technical Report. Cambridge: UNEP-WCMC; 2011.

UNU-IHDP \& UNEP. Inclusive wealth report 2012. Measuring progress toward sustainability. Cambridge: Cambridge University Press; 2012.

Valuing Nature Network. Town Meeting. http://www.valuing-nature.net/about/background, 2011.

Wolters M, Garbutt A, Bekker RM, Carey PD. Restoration of salt-marsh vegetation in relation to site suitability, species pool and dispersal traits. J Appl Ecol 2008; 45: 904-12. 